\title{
ANALISIS MUATAN MATERI SENAM PADA BAHAN AJAR PJOK SEKOLAH DASAR NEGERI DI KOTA BENGKULU.
}

\author{
Agustanul Akmal \\ Penjas Fkip Unib, e-mail: agustanulmuaradanau@gmail.com \\ Tono Sugihartono \\ Universitas Bengkulu \\ Bogy Restu Ilahi \\ Universitas Bengkulu
}

\begin{abstract}
Abstrak
Pembelajarannya dirancang berbasis aktivitas terkait dengan sejumlah jenis gerak jasmani/olahraga dan usaha-usaha menjaga kesehatan yang sesuai untuk peserta didik. Aktivitas-aktivitas tersebut dirancang untuk membuat peserta didik terbiasa melakukan gerak jasmani dan berolahraga dengan senang hati karena merasa perlu melakukannya dan sadar akan pentingnya menjaga kesehatan jasmani baik melalui gerak jasmani dan olahraga maupun dengan memperhatikan faktor-faktor kesehatan yang mempengaruhinya. Penelitian ini merupakan penelitian studi kepustakaan (Library research) dan studi dokumentasi. Jenis penelitian yang digunakan adalah kualitatif. Penelitian ini bertujuan untuk mengetahui muatan materi senam pada bahan ajar pjok di Sekolah Dasar Negeri di Kota Bengkulu.
\end{abstract}

Kata Kunci : Muatan Materi, Bahan Ajar, Senam.

\begin{abstract}
The learning is designed to be based Activities related to A number of types Physical motion or sport And efforts Maintain appropriate health For learners The activities are designed Make learners Accustomed to move Body and sports with pleasure Because feel Need to do it and Aware of the importance Maintaining physical health Either through motion Body and sports As well as with regard Health factors Which influenced him. This study is Research literature study library research And documentation studies. The type of research that is Used is qualitative. The aim of this study To know availability Gymnastics learning materials In Primary School Country in Bengkulu City.
\end{abstract}

Keywords: Content, Materials, Gymnastics.

\section{Pendahuluan}

Pendidikan jasmani pada hakikatnya adalah proses yang memanfaatkan aktivitas fisik untuk menghasilkan perubahan holistik dalam kualitas individu, baik dalam hal fisik, mental, serta emosi. Pendidikan jasmani merupakan anak sebagai sebuah kesatuan utuh, mahluk total dari pada hanya menganggap pendidikan jasmani sebagai yang terpisah kualitas fisik dan mentalnya, (Mahendra 2012: 3) Keterampilan sikap sehat jasmani dan rohani merupakan aspek yang mendasar dan tidak kalah penting, karena merupakan modal individu khususnya siswa untuk dapat melakukan kegiatan dalam berbagai persoalan belajar. 
siswa yang memiliki keterampilan sikap sehat jasmani dan rohani dapat mengarahkan diri ke berbagai keterampilan baru dan mampu mengembangkan kapasitasnya untuk terus hidup melalui kreativitas sepanjang masa dan mampu lebih optimis dalam belajar karena memiliki keadaan jasmani dan rohani yang sehat.

Kurikulum 2013 dirancang untuk memperkuat kompetensi siswa dari sisi pengetahuan, keterampilan, dan sikap secara utuh. Keutuhan tersebut menjadi dasar dalam perumusan kompetensi dasar tiap mata pelajaran, mencakup kompetensi dasar kelompok sikap, kompetensi dasar kelompok pengetahuan, dan kompetensi dasar kelompok keterampilan.

Sebagai mata pelajaran yang mengandung unsur muatan lokal, tambahan materi yang digali dari kearifan lokal dan relevan dengan mata pelajaran ini sangat diharapkan untuk ditambahkan sebagai pengayaan dari bahan ajar materi penjas. Usaha minimal yang harus dilakukan siswa untuk mencapai kompetensi yang diharapkan. Sesuai dengan pendekatan yang digunakan dalam Kurikulum 2013, siswa diajak menjadi berani untuk mencari sumber belajar lain yang tersedia dan terbentang luas di sekitarnya. Peran guru dalam meningkatkan dan menyesuaikan daya serap siswa dengan ketersediaan kegiatan pada buku senam sangat penting. Guru dapat memperkayanya dengan kreasi dalam bentuk kegiatan-kegiatan lain yang sesuai dan relevan yang bersumber dari lingkungan sosial dan alam.

Senam merupakan suatu cabang olahraga yang melibatkan performa gerakan yang membutuhkan kekuatan, kecepatan, dan keserasian gerakan fisik yang teratur. Bentuk modern dari senam ialah palang tak seimbang, balok keseimbangan, senam lantai. Bentuk-bentuk tersebut konon berkembang dari latihan yang digunakan oleh bangsa Yunani. Senam biasa digukakan orang untuk rekreasi, relaksasi atau menenangkan pikiran, biasanya ada yang melakukannya di rumah, ditempat fitness, di gymnasium maupun di sekolah. Saat ini sejak kecil banyak anak sudah terbiasa diajarkan senam, baik oleh orangtua, maupun oleh pengajar olahraga di sekolah. Senam sangat penting untuk pembentukan kelenturan tubuh, yang menjadi arti penting bagi kelangsungan hidup manusia. Senam ada berbagai macam, diantaranya senam lantai, senam hamil, senam aerobic, senam pramuka, senam kesegaran jasmani (SKJ) dan lain sebagainya (Ade Mardiana, 2012:90)

Upaya dalam mengatasi berbagai permasalahan tersebut intinya bergantung dari guru pendidikan jasmani itu sendiri. Guru pendidikan jasmani harus paham dan cermat dalam memuat materi senam pada buku penjaskes. Berbagai model pembelajaran dapat digunakan oleh guru pendidikan jasmani sebagai cara dalam memunculkan dan meningkatkan hasil belajar siswa saat terlibat aktif dalam pembelajaran seperti senam.

\section{METODE}

Penelitian ini merupakan penelitian studi kepustakaan (Library research) dan studi dokumentasi. Jenis penelitian yang digunakan adalah kualitatif (Nana, 2011: 94) bertolak pada filsafat kontruktivisme yang berasumsi bahwa kenyataan itu berdimensi jamak. Adapun SD yang menjadi sampel dalam penelitian ini adalah SD Negeri 20 Kecamatan Gading Cempaka, SD Negeri 75 Kecamatan Kampung Melayu, SD Negeri 69 Kecamatan Muara Bangkahulu, SD Negeri 62 Kecamatan ratu agung, SD Negeri 02 Kecamatan Ratu samban, SD Negeri 74 Kecamatan Selebar, SD Negeri 60 Kecamatan Singaran Pati, SD Negeri 25 Kecamatan Sungai Serut dan SD Negeri 1 kecamatan Teluk Segara.

\section{HASIL DAN PEMBAHASAN}

Setelah melakukan penelitian ke beberapa SD yang ada di Kota Bengkulu 
bahwa guru penjas memiliki bermacammacam bahan ajar yang digunakan pada pembelajaran penjaskes khususnya materi yang digunakan pada senam. Peneliti melakukan observasi langsung ke SD Negeri yang dijadikan sampel dalam penelitian ini

Kurikulum yang digunakan pada Sekolah

Dasar Negeri di Kota Bengkulu

Pada dasarnya SD Negeri yang ada di Kota Bengkulu sudah menggunakan kurikulum K13 seperti yang dapat dilihat pada tabel berikut:

Tabel 1.

Kurikulum yang digunakan pada Sekolah Dasar Negeri di Kota Bengkulu

\begin{tabular}{|c|c|c|}
\hline No. & $\begin{array}{l}\text { Nama } \\
\text { Sekolah }\end{array}$ & $\begin{array}{c}\text { Kurikulum Yang } \\
\text { digunakan }\end{array}$ \\
\hline 1 & SD Negeri 1 & K13 \\
\hline 2 & SD Negeri 2 & K13 \\
\hline 3 & $\begin{array}{c}\text { SD Negeri } \\
20\end{array}$ & K13 \\
\hline 4 & $\begin{array}{c}\text { SD Negeri } \\
25\end{array}$ & KTSP \\
\hline 5 & $\begin{array}{c}\text { SD Negeri } \\
60\end{array}$ & K13 \\
\hline 6 & $\begin{array}{c}\text { SD Negeri } \\
62\end{array}$ & K13 \\
\hline 7 & $\begin{array}{c}\text { SD Negeri } \\
69\end{array}$ & K13 \\
\hline 8 & $\begin{array}{c}\text { SD Negeri } \\
74\end{array}$ & K13 \\
\hline 9 & $\begin{array}{ll}\text { SD } & \text { Negeri } \\
75 & \end{array}$ & KTSP \\
\hline
\end{tabular}

Pada dasarnya SD Negeri yang ada di Kota Bengkulu sudah menggunakan kurikulum K13, tetapi pada penerapan untuk PJOK belum dilakukan oleh pihak sekolah. Cara dan proses pembelajaran PJOK masih dilakukan KTSP. Adapun SD Negeri yang belum meggunakan kurikulum K13 adalah SD Negeri 75 dan SD Negeri 25, sedangkan SD yang telah menerapkan kurikulum K13 kelas 1 sampai 6 adalah SD Negeri 1 dan SD Negeri 20.

\section{Bahan Ajar Penjas yang digunakan pada Sekolah Dasar Negeri di Kota Bengkulu \\ Untuk ketersediaan bahan ajar sekolah dasar Negeri di Kota Bengkulu dapat dilihat pada tabel berikut:}

Tabel 2.

Bahan ajar penjas pada Sekolah dasar Negeri di Kota Bengkulu

\begin{tabular}{r|l|l} 
No & NamaSekolah & $\begin{array}{c}\text { Bahan Ajar Penjas } \\
\text { yang tersedia }\end{array}$ \\
\hline 1 & SD Negeri 1 & Buku \\
\hline 2 & SD Negeri 2 & $\begin{array}{c}\text { Buku, Media Gambar } \\
\text { Alat Olahraga }\end{array}$ \\
\hline 3 & SD Negeri 20 & $\begin{array}{c}\text { Buku dan bahan ajar } \\
\text { dari internet }\end{array}$ \\
\hline 4 & SD Negeri 25 & Buku \\
\hline 5 & SD Negeri 60 & Buku \\
\hline 6 & SD Negeri 62 & Buku \\
\hline 7 & SD Negeri 69 & Buku \\
\hline 8 & SD Negeri 74 & Buku \\
\hline 9 & SD Negeri 75 & Buku \\
\multicolumn{3}{|c}{ Sumber : Hasil Penelitian, 2017 }
\end{tabular}

Berdasarkan tabel di atas, dapat dilihat bahwa rata-rata sekolah belum menggunakan bahan ajar lainnya selain buku.

\section{Ketersediaan Buku}

Berdasarkan hasil penelitian yang telah dilakukan oleh peneliti mengenai muatan materi senam pada bahan ajar guru pada masing-masing sekolah. Bahan ajar mulai dari kelas I sampai kelas VI pegangan siswa dan guru memuat materi tentang senam. Adapun keterangan dari bahan ajar buku yang ada di sekolah dasar negeri di Kota Bengkulu dapat dilihat pada tabel berikut:Ketersediaan Gambar

Selain bahan ajar buku, maka ketersediaan gambar pada Sekolah dasar Negeri yang ada di Kota Bengkulu sebagai berikut: 
Tabel 3.

Ketersediaan gambar sebagai bahan ajar pada sekolah dasar Negeri di Kota Bengkulu

\begin{tabular}{|c|c|c|}
\hline $\mathbf{N}$ & $\begin{array}{l}\text { Nama } \\
\text { Sekolah }\end{array}$ & $\begin{array}{l}\text { BahanAjar Penjas } \\
\text { yang tersedia }\end{array}$ \\
\hline 1 & SD Negeri 1 & Tidak Tersedia \\
\hline 2 & SD Negeri 2 & Tersedia \\
\hline 3 & $\begin{array}{c}\text { SD Negeri } \\
20 \\
\end{array}$ & Tidak Tersedia \\
\hline 4 & $\begin{array}{c}\text { SD Negeri } \\
25\end{array}$ & Tidak Tersedia \\
\hline 5 & $\begin{array}{c}\text { SD Negeri } \\
60\end{array}$ & Tidak Tersedia \\
\hline 6 & $\begin{array}{c}\text { SD Negeri } \\
62 \\
\end{array}$ & Tidak Tersedia \\
\hline 7 & $\begin{array}{c}\text { SD Negeri } \\
69 \\
\end{array}$ & Tidak Tersedia \\
\hline 8 & $\begin{array}{c}\text { SD Negeri } \\
74\end{array}$ & Tidak Tersedia \\
\hline 9 & $\begin{array}{c}\text { SD Negeri } \\
75\end{array}$ & Tidak Tersedia \\
\hline
\end{tabular}

Sumber : Hasil Penelitian, 2017

Berdasarkan hasil penelitian yang telah dilakukan oleh peneliti di SD Negeri yang ada di kota Bengkulu bahwa bahan ajar yang digunakan untuk pembelajaran senam masih kurang variatif. Guru hanya menggunakan beberapa buku cetak. Hanya beberapa sekolah saja yang sudah menggunakan bahan ajar dengan bantuan teknologi seperti bahan ajar yang diambil dari internet.

Pemilihan bahan ajar yang seharusnya dilakukan oleh guru penjas yang ada di Kota Bengkulu, yaitu diantaranya sebagai berikut. Pertama, menentukan kriteria pokok pemilihan bahan ajar dengan mengidentifikasi Standar Kompetensi (SK) dan Kompetensi Dasar (KD). Hal ini dikarenakan setiap aspek dalam SK dan KD jenis materi yang berbeda-beda dalam kegiatan pembelajaran. Kedua, mengidentifikasi jenis-jenis materi bahan ajar. Materi pembelajaran dibedakan menjadi jenis materi aspek kognitif (fakta, konsep, prinsip dan prosedur), aspek afektif (pemberian respon, penerimaan, internalisasi, dan penilaian) serta aspek psikomotorik (gerakan awal, semi rutin, dan rutin). Keempat, memilih bahan ajar yang sesuai atau relevan dengan SK-KD yang telah teridentifikasi tadi. Kelima, memilih sumber bahan ajar. Tahapan setelah menentukan jenis materi ialah menentukan sumber bahan ajar.

Memperhatikan prosedur pemilihan bahan ajar ini, diharapkan pembelajaran pendidikan jasmani akan terhindar dan jauh dari kesan sebagai pelajaran yang membosankan dan tidak menantang. Keterampilan didefiniskan sebagai kemampuan menggunakan satu pemahaman untuk menyelesaikan tugas secara efektif dan selesai. Sebagai contoh, bagaimana siswa SD terampil dalam mengungkapan informasi secara kongkrit berupa majalah bergambar, seperti melalui peta, globe, grafik, jam, kalender dan garis waktu membuat grafik, bagaimana menggunakan ensklopedia, bagaimana membaca kontur peta/globe/pembagian waktu, bagaimana membedakan fakta dari opini, bagaimama membuat keputusan bersama secara demokratis mengenai pendidikan jasmani dan kesehatan khususnya materi senam.

Membantu memudahkan memahami keempat jenis materi pembelajaran tersebut, berikut ini disajikan contoh diagram proses pemilihan materi pembelajaran dalam pelajaran penjas SD.

Ketika guru harus menyajikan materi pembelajaran yang termasuk jenis fakta (nama-nama benda, nama tempat/lokasi, peristiwa sejarah, nama orang, berapa jumlah dan lain sebagainya) strategi yang tepat untuk mengajarkan materi tersebut adalah dengan cara menyajikan materi fakta dengan lisan, tulisan, gambar, foto, CD Pembelajaran, pemanfaatan lingkungan sekitar, dan memberikan bantuan kepada 
siswa untuk menghafal. Tujuan mempelajari konsep adalah agar siswa paham yang mampu mendefinisikan, menunjukkan ciriciri, unsur, membedakan, membandingkan, mengelompokan. Bila menggunakan strategi pengajaran langsung, langkah-langkah yang dapat ditempuh guru dalam mengajarkan konsep: pertama, sajikan konsep dengan terlebih dahulu menuliskan abstraksi di papan tulis, layar OHP atau media presentasi lainnya; kedua, berikan bantuan (berupa inti isi, ciri-ciri pokok, contoh dan bukan contoh); ketiga, berikan latihan (exercise) misalnya berupa tugas untuk mencari contoh lain; keempat, berikan umpan balik, dan kelima, berikan tes

\section{PENUTUP}

\section{Simpulan}

Berdasarkan data-data yang terkumpul terkait dengan ketersediaan penggunaan bahan ajar materi senam sangat ditentukan oleh penerapan kurikulum yang digunakannya. Sebagian besar sudah menggunakan kurikulum 2013 (K.13) dan sebagian sekolah masih menggunakan KTSP. Materi yang digunakan oleh guru PJOK masih banyak menggunkan buku yang memuat senam pada kurikulum KTSP dikarenakan buku PJOK pada kurikulum 2013 tidak memuat secara jelas mencantumkan materi senam, Materi senam dapat diterapkan pada tema-tema terkait. Pada setiap sekolah dasar bahan ajar baik buku maupun bahan ajar lainya seperti bahan ajar non buku atau cetak seperti file softcopy yang tersimpan di computer seperti video pembelajaran/video instruksional, gambar, alat peraga youtube, jurnal, ebook dan power point.

\section{Saran}

Bagi guru olahraga, berdasarkan pada hasil penelitian ini, maka disarankan kepada guru olahraga untuk lebih kreatif lagi dalam menggunakan bahan ajar, Banyak jenis bahan ajar yang bisa digunakan untuk menambah pengetahuan siswa. Tidak hanya bahan ajar media cetak tetapi alat peraga, ensiklopedi, bahan ajar berupa power point, video pembelajaran, softcopy, jurnal, dan ebook, yang bisa lebih meningkatkan pengetahuan siswa secara nyata mengenai pembelajaran senam.

Dalam penelitian ini karena sampel penelitian masih terbatas maka disarankan kepada peneliti lain, yang ingin meneliti hal yang sama, agar memperbanyak sampelnya. Bagi pihak sekolah agar memberikan fasilitas bahan ajar yang memadai bagi guru penjas untuk melakukan pembelajaran senam di sekolah

\section{DAFTAR PUSTAKA}

Ade Mardiana,dkk. (2008). Pendidikan jasmani dan Olahraga. Jakarta: Universitas Terbuka

Direktorat Jenderal Pendidikan Dasar dan Menengah Depdiknas (2006)

Hamalik, Oemar, (2010). Pendidikan Guru Berdasarkan Pendekatan Kompetensi, Jakarta: PT. Bumi Aksara, Cet, Ke-7

Mahendra, Agus. (2012). Model Pembelajaran Pendidikan Jasmani Kumpulan makalah bahan penataran. file.upi.edu.

Soni, Tono, dan Yarmani. 2017. "Kontribusi Kelentukan Pinggang dan Power Otot Lengan Pada Keterampilan Stutz Senam Lantai”. Jurnal Kinestetik, Vol. 1 (1).

Tangkudung, James. (2012). Kepelatihan Olahraga Pembinaan Prestasi Olahraga. Jakarta: Cerdas jaya ,(2016).Macam-macam Metodologi Penelitian. Jakarta: Lensa Media Pustaka Indonesia 